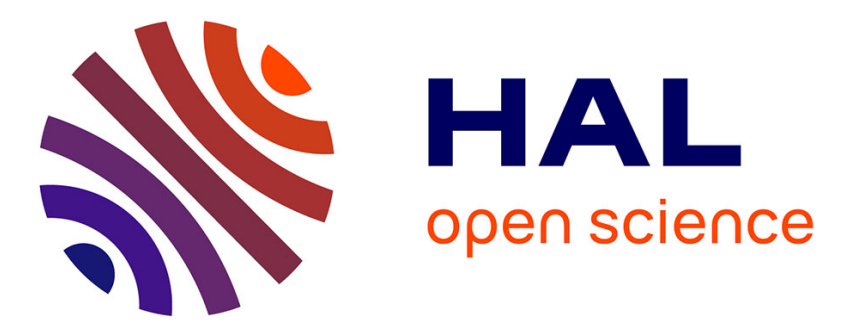

\title{
Routine determination of inorganic arsenic speciation in precipitates from acid mine drainage using orthophosphoric acid extraction followed by HPLC-ICP-MS
}

E. Resongles, P. Le Pape, L. Fernandez-Rojo, G. Morin, S. Delpoux, J. Brest, S. Guo, C. Casiot

\section{To cite this version:}

E. Resongles, P. Le Pape, L. Fernandez-Rojo, G. Morin, S. Delpoux, et al.. Routine determination of inorganic arsenic speciation in precipitates from acid mine drainage using orthophosphoric acid extraction followed by HPLC-ICP-MS. Analytical Methods, 2016, 8 (40), pp.7420-7426. 10.1039/C6AY02084D . hal-02086956

\section{HAL Id: hal-02086956 https://hal.science/hal-02086956}

Submitted on 31 May 2021

HAL is a multi-disciplinary open access archive for the deposit and dissemination of scientific research documents, whether they are published or not. The documents may come from teaching and research institutions in France or abroad, or from public or private research centers.
L'archive ouverte pluridisciplinaire HAL, est destinée au dépôt et à la diffusion de documents scientifiques de niveau recherche, publiés ou non, émanant des établissements d'enseignement et de recherche français ou étrangers, des laboratoires publics ou privés. 


\section{Routine determination of inorganic arsenic speciation in precipitates from acid mine drainage using orthophosphoric acid extraction followed by HPLC-ICP-MS}

Resongles E. ${ }^{a}$, Le Pape P. ${ }^{b}$, Fernandez-Rojo L. ${ }^{a}$, Morin G. ${ }^{b}$, Delpoux S. ${ }^{a}$, Brest J. , Guo S. ${ }^{b}$, Casiot C. ${ }^{a^{*}}$

${ }^{a}$ HydroSciences Montpellier UMR 5569, Université Montpellier, CNRS, IRD, CC 57, 163 Rue Auguste Broussonet, F-34090 Montpellier, France.

${ }^{\mathrm{b}}$ Sorbonne Universités - Institut de Minéralogie, de Physique des Matériaux et de Cosmochimie (IMPMC), UMR UPMC-CNRS-IRD-MNHN 7590, UPMC Université Paris VI, 4 place Jussieu, 75252 Paris cedex 05, France.

*Corresponding author: corinne.casiot-marouani@umontpellier.fr

\section{Abstract}

A simple chemical extraction method is proposed for the routine determination of the proportions of $\mathrm{As}(\mathrm{III})$ and $\mathrm{As}(\mathrm{V})$ species in iron-rich precipitates originating from acid mine drainage (AMD). The procedure consists of an orthophosphoric acid (1 M) extraction and subsequent analysis of As(III) and As(V) concentrations in the extract by HPLC-ICP-MS. The proposed method was validated on a series of synthetic As(III)/As(V)-schwertmannite samples and of AMD samples exhibiting various mineralogical compositions, total As concentration, $\mathrm{As} / \mathrm{Fe}$ and $\mathrm{As}(\mathrm{III}) / \Sigma \mathrm{As}$ ratios as determined by X-Ray Diffraction (XRD), total digestion-ICPMS and synchrotron-based X-ray Absorption Near Edge Structure spectroscopy (XANES), respectively. High arsenic extraction efficiency (99 $\pm 10 \%$ of total As) was achieved with orthophosphoric acid since As-bearing iron phases that form in AMD are poorly crystalline. $\mathrm{As}(\mathrm{III})$ and $\mathrm{As}(\mathrm{V})$ proportions determined using the chemical extraction method followed by HPLC-ICP-MS analysis well matched the arsenic redox data obtained from the As K-edge XANES spectra analysis, showing the possibility to routinely measure As oxidation state in AMD precipitates using this new simple extraction method. 


\section{Introduction}

High levels of arsenic (As), in the form of As(III) and As(V), commonly occur in acid mine drainage (AMD) due to the oxidative dissolution of As-rich sulfidic ores. ${ }^{1-3}$ Natural attenuation processes of AMD are known to involve microbially mediated Fe- and As-oxidation and precipitation, thus, limiting the dissemination of arsenic throughout downstream hydrosystems. ${ }^{4,5}$ Both As(III) and As(V) species can sorb to secondary Fe-oxyhydroxides as ferrihydrite ${ }^{6}$ and Fe-oxyhydroxysulfates such as schwertmannite. ${ }^{7,8}$ Arsenic(V) can also be incorporated in jarosite that forms below $\mathrm{pH} 2$ in AMDs. ${ }^{9}$ For extreme As concentrations, Ascontaining minerals such as amorphous ferric arsenate ${ }^{10,11}$ and tooeleite ${ }^{4}$ may also form.

Since $\mathrm{As}(\mathrm{III})$ and $\mathrm{As}(\mathrm{V})$ have different geochemical behaviors and toxicity to the ecosystems, the knowledge of As oxidation state in secondary Fe-precipitates that form in AMD is essential to evaluate arsenic impacts to these environments and to optimize remediation strategies. Synchrotron-based techniques as X-ray Absorption Spectroscopy (XAS) greatly improved our understanding of As behavior and attenuation processes in AMD-impacted environments by providing detailed information about As oxidation state in the solid phase using X-ray Absorption Near Edge Structure (XANES) spectroscopy and its distribution among As-bearing phases using Extended X-ray Absorption Fine Structure (EXAFS). ${ }^{7-9,11-15}$ However, synchrotron-based XAS is unlikely to be used as a routine technique for monitoring As speciation in large sets of samples from field and remediation systems.

Chemical extractions followed by speciation analysis using hyphenated techniques (e.g. HPLCICP-MS, HPLC-HG-AFS) have been widely used to determine As oxidation state in soils and sediments. ${ }^{16-26}$ However, these methods have not been tested and validated for the determination of As oxidation state in Fe-precipitates from AMD. Arsenic extraction from the solids represents a critical step because total As solubilization is not always achieved using 'soft' extractants, the most common being orthophosphoric acid ${ }^{21-23}$, while more aggressive extractants such as concentrated hydrochloric acid can fail in preserving As oxidation state. ${ }^{24-}$ ${ }^{26}$ One major issue with regard to AMD samples was the presence of high amount of $\mathrm{Fe}$ (III) that is suspected to oxidize As(III) during the extraction step. ${ }^{26}$

The objective of this study was to develop and validate a simple chemical extraction method for the routine determination of As oxidation state in As-rich Fe-precipitates that form in AMDimpacted streams and in AMD remediation technologies. This method relies on an 
orthophosphoric acid extraction followed by HPLC-ICP-MS (High Performance Liquid Chromatography coupled to Inductively Coupled Plasma Mass Spectrometry) analysis. Validation has been performed by comparison with XANES spectroscopy. Moreover, robustness of the extraction method was tested by applying this method on a variety of AMD samples exhibiting various mineralogy, As content, $\mathrm{As} / \mathrm{Fe}$ and $\mathrm{As}(\mathrm{III}) / \Sigma \mathrm{As}$ ratios, and on synthetic As(III)/As(V)-schwertmannite samples.

\section{Materials and methods}

\subsection{Standards and reagents}

Double deionized water (18.2 $\mathrm{M} \Omega \mathrm{cm}^{-1}$ ) from a Milli-Q system (Millipore) was used for all experiments. Total digestion and chemical extractions were performed using reagents of Suprapur® quality $\left(35 \% \mathrm{H}_{2} \mathrm{O}_{2}, 30 \% \mathrm{HCl}\right.$ and $65 \% \mathrm{HNO}_{3}$, Merck) or analytical grade $(85 \%$ $\mathrm{H}_{3} \mathrm{PO}_{4}$, VWR Chemicals).

Two solutions, one consisting of $8.7 \mathrm{M}$ acetic acid (VWR Chemicals, analytical grade, 100\%) and the other one made with $50 \mathrm{~g} \mathrm{~L}^{-1}$ EDTA disodium salt (Chem-Lab, ACS reagent, 99-101\%) were used to preserve As speciation in standard solutions and diluted samples before analysis. ${ }^{27}$ These solutions were stored in the dark at $4{ }^{\circ} \mathrm{C}$ and kept for 6 months.

Arsenic(III) and As(V) standard solutions (1000 $\mathrm{mg} \mathrm{L}^{-1}$ ) were prepared by dissolving an appropriate amount of $\mathrm{NaAsO}_{2}$ (Sigma-Aldrich, $\geq 90 \%$ ) and $\mathrm{Na}_{2} \mathrm{HAsO}_{4}$ (Sigma-Aldrich, ACS reagent, 98,0-102,0\%), respectively, in double deionized water. These solutions were stored in the dark at $4{ }^{\circ} \mathrm{C}$ and their stability was frequently checked. An intermediate standard solution containing a mixture of $\mathrm{As}(\mathrm{III})$ and $\mathrm{As}(\mathrm{V})\left(10 \mathrm{mg} \mathrm{L}^{-1}\right.$ each) was prepared daily and preserved with $1 \% \mathrm{v} / \mathrm{v}$ acetic acid and $1 \% \mathrm{v} / \mathrm{v}$ EDTA solution. It was used for the preparation of calibration solutions in the same medium ( $1 \% \mathrm{v} / \mathrm{v}$ acetic acid-EDTA solution). Ammonium phosphate buffer ( $\mathrm{pH} 8.0,30 \mathrm{mM}$ ), used as HPLC mobile phase, was prepared from analytical grade $\mathrm{NH}_{4} \mathrm{H}_{2} \mathrm{PO}_{4}$ (Merck) and $\left(\mathrm{NH}_{4}\right)_{2} \mathrm{HPO}_{4}$ (Fisher Scientific).

\subsection{Samples}

A set of 29 samples representative of $\mathrm{Fe}$-As precipitates commonly found in AMD-impacted streams was used in this study. These samples were selected for their variability with regard to mineralogy, total As content, As/Fe ratio and $\mathrm{As}(\mathrm{III}) / \Sigma \mathrm{As}$ ratio $(\Sigma \mathrm{As}=\mathrm{As}(\mathrm{III})+\mathrm{As}(\mathrm{V}))$. 
Seven As-rich sediment samples, referred to as F1 to F7 (Table 1), originated from an AMDimpacted stream at the former $\mathrm{Pb} / \mathrm{Zn}$ Carnoulès mine (Gard, France), four of which having been previously characterized (mineralogy, As content, As/Fe and $\mathrm{As}(\mathrm{III}) / \Sigma \mathrm{As}$ ratios) by Morin et al. ${ }^{5}$ After field sampling, solids were centrifuged and vacuum dried and preserved in sealed containers.

Seventeen further Fe-As precipitate samples, referred to as 0-G1 to 3B-G4 (Table 1) originated from a laboratory pilot system dedicated to biological treatment of Carnoulès AMD-water. After collection of the solid samples, one subsample was placed in a vacuum desiccator, dried until constant weight and stored at $4{ }^{\circ} \mathrm{C}$ in sealed bag for further determination of total As and Fe content, together with As speciation using chemical extraction. Another subsample was dried in a glove box under Ar atmosphere for further characterization of the mineralogy and As speciation determination using X-Ray Diffraction (XRD) and XANES spectroscopy, respectively.

Finally, five synthetic reference samples, referred to as 100/0 to 0/100 (Table 1) consisted of mechanical mixtures of synthetic As(III)- and As(V)-sorbed schwertmannite were used as proxies for AMD mineral phases with well controlled As speciation. Prior to As sorption, schwertmannite was synthesized according to Barham $^{28}$ as detailed in the Supplementary Information (Section 1). After the exact chemical composition of each As(III) and As(V)sorbed schwertmannite endmember was checked following the protocol described in the Supplementary Information (Section 2), mechanical mixtures of As(III)schwertmannite/As(V)-schwertmannite were produced by mixing appropriate masses and kept under anoxic atmosphere until analysis.

\subsection{Sample characterization}

\section{3.a. Total arsenic and iron concentrations}

Total As and Fe concentrations were determined using a routine method involving an aqua regia digestion and ICP-MS analysis (see the Supporting Information, Section 2 for details); except for F1, F2, F3 and F4 samples, whose total As and Fe concentrations had been determined previously by electron microprobe analysis. ${ }^{5}$ 


\section{3.b. Mineralogy $(X R D)$}

Powder XRD measurements were performed with Co K $\alpha$ radiation using a Panalytical X'Pert Pro diffractometer. Depending on the amount of solid available, solids were either analysed as bulk powders in appropriate sample holders or were deposited on silicon single-crystal lowbackground sample holders. Data were collected in continuous mode between 5 and $80{ }^{\circ} 2 \theta$ with a $0.033^{\circ} 2 \theta$ step, counting $\sim 4$ h per sample.

\section{3.c. Arsenic oxidation state determined by XANES spectroscopy}

Arsenic K-edge XANES spectra of samples were collected both at $15 \mathrm{~K}$ in transmission mode on the SAMBA beamline (SOLEIL, Saint-Aubin, France) using a Si(220) double-crystal monochromator, equipped with dynamic sagittal focusing of the second crystal and in transmission mode at $80 \mathrm{~K}$ on the XAFS beamline (ELETTRA, Trieste, Italy) using a Si(111) double-crystal monochromator. To preserve As oxidation state during these analyses, samples were mounted on the cryostat sample rod within a glovebox next to the beamline and quickly transferred into the cryostat. The incident beam energy was calibrated by setting to $11947 \mathrm{eV}$ the energy position of the absorption maximum in the $\mathrm{L}_{\mathrm{III}}$-edge of an Au foil recorded in doubletransmission setup.

XANES linear combination fits (LCF) using As(III) and As(V) model compounds were performed using an homemade program based on a Levenberg-Marquardt algorithm. Model compounds used to fit the experimental spectra were As(III) and As(V) coprecipitated schwertmannites ${ }^{11}$ and tooeleite ${ }^{5}$ (Supplementary Information, Figure S1). The fit quality was estimated using a reduced $\chi^{2}$ as follows:

$$
\chi^{2} \mathrm{R}=1 /\left(N_{\text {ind }}-N_{\mathrm{p}}\right) \sum_{\mathrm{i}=1, \mathrm{n}}\left[\mu(E) \exp _{\mathrm{i}}-\mu(E) \mathrm{calc}_{\mathrm{i}}\right]^{2}
$$

with $N_{\text {ind }}=\Delta E / N W(\Delta E$ : energy fitting range; $N W$ : natural width of the As $K$ level $)$ the number of independent parameters, $N_{\mathrm{p}}$ the number of fitting components, $\mu(E) \exp _{\mathrm{i}}$ and $\mu(E) \mathrm{calc}_{\mathrm{i}}$ the experimental and calculated data point $i$. Uncertainty on each refined parameter was estimated as $3 \times \sqrt{\operatorname{VAR}(p) \chi_{R}^{2}}$, where $\operatorname{VAR}(p)$ is the variance of parameter $p$ returned by the LevenbergMarquardt routine for the lowest $\chi^{2}{ }_{\mathrm{R}}$ value. 
2.4. Arsenic speciation by chemical extraction and HPLC-ICP-MS analysis

\section{4.a. Chemical extraction procedure}

Chemical extractions were carried out using 50 to $100 \mathrm{mg}$ of milled samples depending on the amount of available material. Samples were heated at $95{ }^{\circ} \mathrm{C}$ during $1 \mathrm{~h}$ on a hot plate with $15 \mathrm{~mL}$ of $1 \mathrm{M} \mathrm{H}_{3} \mathrm{PO}_{4}$ in a polypropylene tube, under darkness and with manual shaking every 10 minutes. After the extraction step, samples were allowed to cool to room temperature and were filtered using a polypropylene syringe and a cellulose acetate syringe filter $(0.22 \mu \mathrm{m})$. The first drops of the filtered extract were not recovered, allowing the syringe filter to be rinsed out. Due to the high As content in the studied samples (31-240 $\mathrm{mg} \mathrm{g}^{-1}$ ), extracts were diluted from 2000 to 10,000 times with an acid acetic-EDTA solution $(1 \% \mathrm{v} / \mathrm{v})$ before injection in HPLCICP-MS. Speciation analyses were carried within $6 \mathrm{~h}$ after extraction.

To check that no As(III) oxidation occurred during the extraction procedure, $100 \mathrm{mg}$ of a selected sample (F7) was extracted with $15 \mathrm{~mL}$ of $1 \mathrm{M} \mathrm{H}_{3} \mathrm{PO}_{4}$ spiked with a known amount of As(III) standard solution (corresponding to a two-fold increase of total As concentration) just before the extraction. Additionally, the stability of As redox speciation in orthophosphoric acid extracts throughout time was assessed. For that, extracts were immediately analysed by HPLCICP-MS after the extraction (T0). An aliquot of the extract was diluted 100-times in $1 \% \mathrm{v} / \mathrm{v}$ acetic acid-EDTA solution. Then, extracts and diluted extracts were kept at $4{ }^{\circ} \mathrm{C}$ in the dark and re-analysed with an adequate dilution after 7 (T7) and 35 (T35) days.

Preliminary test of different methods widely used in the literature ${ }^{23,25,26}$ allowed to select orthophosphoric acid extraction on hot plate as the easiest method to implement (Supplementary Information, Section 3 and Figure S2).

\section{4.b. Arsenic(III) and As(V) species analysis by HPLC-ICP-MS}

Determination of $\mathrm{As}(\mathrm{III})$ and $\mathrm{As}(\mathrm{V})$ concentrations in the extracts was carried out by HPLCICP-MS (High Performance Liquid Chromatography coupled to Inductively Coupled Plasma Mass Spectrometry) as described in Héry et al. ${ }^{29}$. A $100 \mu \mathrm{l}$ sub-sample of the diluted extracts was injected into the HPLC system (SpectraSystemP4000, ThermoScientific). Chromatographic separation was performed by elution with a $1 \mathrm{ml} \mathrm{min}^{-1}$ flow of ammonium phosphate buffer ( $\mathrm{pH} 8.0,30 \mathrm{mM})$ through an anion-exchange Hamilton PRP-X100 column (25 cm x $4.1 \mathrm{~mm}$ i.d. $\times 10 \mu \mathrm{m}$ ) equipped with a precolumn (Figure S3 in the Supporting Information). Detection of $\mathrm{As}(\mathrm{III})$ and $\mathrm{As}(\mathrm{V})$ was carried out using an ICP-MS (X Series II, 
ThermoFisher Scientific). Arsenic species were calibrated with standard solutions of As(III) and $\mathrm{As}(\mathrm{V})$ (5-20-100 $\left.\mu \mathrm{g} \mathrm{L}^{-1}\right)$ and Ge was used as internal standard by continuous addition through a T-junction before introduction into ICP-MS. The detection limits were $0.1 \mu \mathrm{g} \mathrm{L} \mathrm{L}^{-1}$ for As(III) and $0.5 \mu \mathrm{g} \mathrm{L}^{-1}$ for As(V). Extraction blanks were performed and both As(III) and As(V) species represented less than $1 \%$ of As measured in samples.

\section{4.c. Uncertaintydetermination}

The uncertainties on the total As concentration ( $\Sigma \mathrm{As}$ ) and $\mathrm{As}(\mathrm{III})$ proportion $(\mathrm{As}(\mathrm{III}) / \Sigma \mathrm{As}$ ) values obtained by chemical extraction and HPLC-ICP-MS analysis were assessed by means of an error propagation calculation taking into account the uncertainties on $\mathrm{As}(\mathrm{III})$ and $\mathrm{As}(\mathrm{V})$ concentrations. The latter were determined by repeating the whole protocol for selected field samples (F5, F6 and F7) and laboratory samples (1A-G4 and 2A-G3) and thus represent the reproducibility of both chemical extraction step and speciation analysis. The results for replicate samples and the detailed calculation of uncertainties are given in the Supplementary Information (Section 4 and Table S1). The relative standard deviations (RSDs) were 2-6\% for total As concentration and 3-11\% for As(III) proportion. The largest RSD values were assigned to samples processed once (i.e. $6 \%$ for $\Sigma$ As and $11 \%$ for $\mathrm{As}(\mathrm{III}) / \Sigma \mathrm{As}$ ). 


\section{3. $\quad$ Results and discussion}

\subsection{Sample characterization}

Arsenic is a major constituent of all studied samples with As content ranging from 31 to $240 \mathrm{mg} \mathrm{g}^{-1}$ (Table 1). The mixtures of synthetic As(III)-/As(V)-schwertmannites had lower As concentration (31-48 $\mathrm{mg} \mathrm{g}^{-1}$ ) than the laboratory AMD-precipitate samples (59-97 $\mathrm{mg} \mathrm{g}^{-1}$ ) and the AMD-sediments collected at the Carnoulès mine (120-240 mg g $\left.\mathrm{g}^{-1}\right)$. Iron concentrations ranged from 36 to $57 \mathrm{wt} \%$ in synthetic schwertmannite mixtures, from 30 to $38 \mathrm{wt} \%$ in laboratory AMD-precipitates and from 16 to $30 \mathrm{wt} \%$ in natural AMD-sediments, with corresponding As/Fe molar ratio of 0.1, 0.1-0.2 and 0.5-0.7, respectively.

Crystalline phases were found in some of the Carnoulès AMD sediment samples including tooeleite $\left(\mathrm{Fe}_{6}\left(\mathrm{AsO}_{3}\right)_{4}\left(\mathrm{SO}_{4}\right)(\mathrm{OH})_{4}, 4 \mathrm{H}_{2} \mathrm{O}\right)$, jarosite $\left(\mathrm{KFe}_{3}\left(\mathrm{SO}_{4}\right)_{2}(\mathrm{OH})_{6}\right)$ and quartz. The dominant phase consists of amorphous ferric arsenate and arsenite. ${ }^{5}$ The laboratory AMD-precipitate samples consisted exclusively of nanocrystalline schwertmannite $\left(\mathrm{Fe}_{8} \mathrm{O}_{8}(\mathrm{OH})_{6} \mathrm{SO}_{4}\right)$ and amorphous ferric arsenate and arsenite. An overview of the mineralogy for each group of samples is given in the Supplementary Information (Figure S4). Previous studies conducted at the Carnoulès mine showed that As was mainly trapped as tooeleite and amorphous ferric arsenate in AMD sediments close to the spring while schwertmannite was present further downstream, once As concentration had decreased in the dissolved phase., ${ }^{4,511}$ Besides, in ageing experiments with Carnoulès AMD water, jarosite formed after most As had been removed from the dissolved phase. ${ }^{30}$ Hence, schwertmannite, tooeleite and amorphous ferric arsenate and arsenite are likely to represent the main As-bearing phases in the AMD samples studied here. 
Table 1: Total As ( $\mathrm{mg} \mathrm{g}^{-1}$ ) and Fe concentrations (wt.\%), As/Fe molar ratio and mineralogy of field and laboratory AMD-precipitates and synthetic As(III)-/As(V)-schwertmannite mixtures.

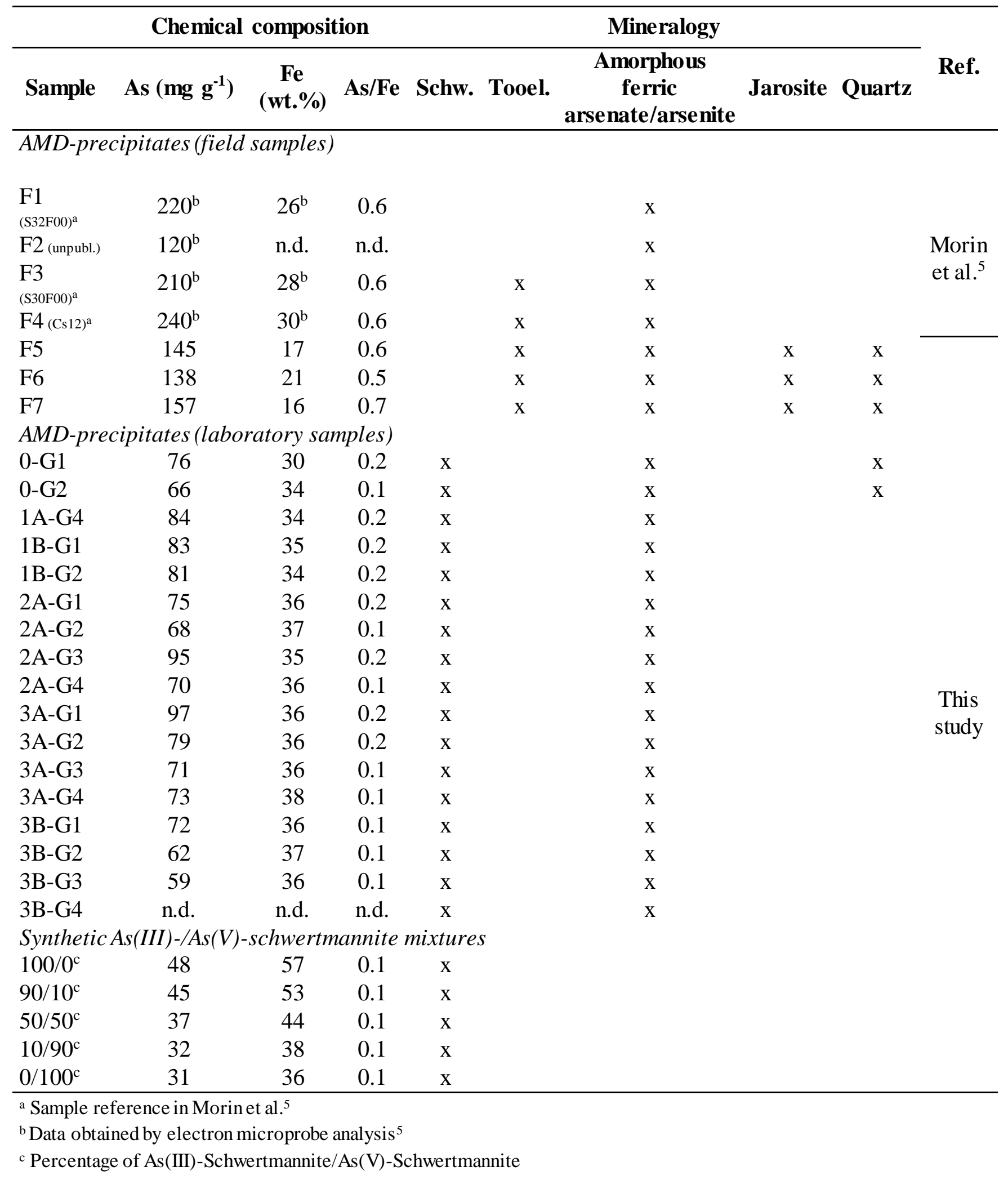




\subsection{Efficiency of the orthophosphoric acid extraction procedure}

The efficiency of the extraction method was assessed with regard to total As extraction yield and As oxidation state preservation. Arsenic extraction yields are calculated by comparing the sum of As(III) and As(V) species ( $\Sigma$ As) measured by chemical extraction and HPLC-ICP-MS analysis with the total As concentration determined by aqua regia digestion and ICP-MS analysis. Arsenic oxidation state preservation was assessed using XANES result as reference data. Bias on As(III) proportion given in section 3.2.b are regression residuals calculated as follows: difference between the value obtained from orthophosphoric acid extraction and the yvalue calculated using the regression equation in Figure $1 \mathrm{~b}$ (orthophosphoric acid extraction vs XANES results) with XANES data as $\mathrm{x}$-value.

\section{2.a. Total arsenic extraction yield}

Total As concentration ( $\Sigma$ As) determined by chemical extraction and HPLC-ICP-MS analysis was in good agreement with that determined by aqua regia digestion and ICP-MS analysis $\left(\mathrm{R}^{2}=0.970\right.$, Figure 1a). Arsenic extraction yields averaged $99 \pm 10 \%(\mathrm{n}=28)$ and by taking into account uncertainties there were no significant differences between results obtained from both methods (Supplementary Information, Table S2), except for three samples namely F7, 3B-G3 and 10/90 schwertmannite mixture for which the extraction yield was 82, 72, and 120\%, respectively. These discrepancies were neither related to the sample type (natural vs. artificial sample), nor to As concentration, As/Fe ratio or mineralogical composition and may rather result from the sample heterogeneity. It is notew orthy that no solid residues were observed in the extracts after the extraction step, except in the presence of quartz (F5, F6, F7, 0-G1 and 0G2 samples). Overall, these results showed that all the studied As-bearing solid phases (i.e. tooeleite, schwertmannite, amorphous ferric arsenate and arsenite) were fully dissolved using a simple orthophosphoric extraction and that As was completely recovered from these phases.

Wide ranges of As extraction yields, from few percent to complete recovery, have been reported in the literature for orthophosphoric acid extraction of soil or sediments samples. ${ }^{17,20-23,25}$ Extraction efficiency appeared to depend on a great extent on the sample composition and the mode of As association with solid phases. Adsorbed As pool can be easily released from solid phases through competition between phosphate ions and As species at the solid surface while structural As in crystalline phases is more difficult to extract and necessitates the dissolution of mineral structures. ${ }^{17,21,24,26}$ However, orthophosphoric acid may also be able to dissolve some mineral phases via proton dissolution and ligand-promoted dissolution mechanisms. ${ }^{21,24}$ In 
AMD environments, freshly formed Fe precipitates usually consist of nanocrystalline, poorly ordered or amorphous phases 5,11 , which make those solids prone to be readily dissolved as observed in this study.
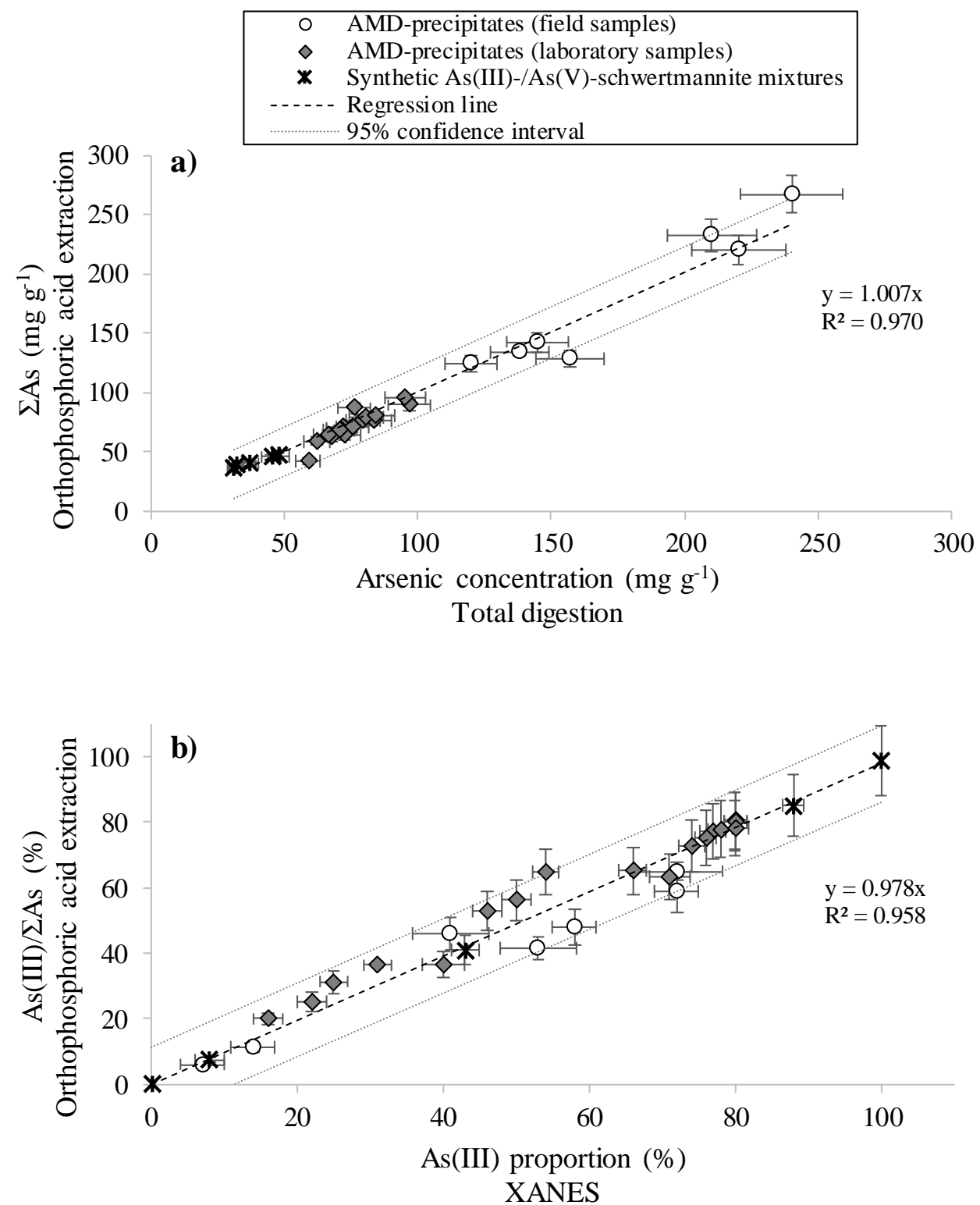

Figure 1: Relationship between a) total As concentration obtained by chemical extraction followed by HPLC-ICP-MS analysis and by total digestion and ICP-MS analysis and b) proportion of As(III) (expressed as a percentage of total As; $\Sigma$ As=As(III)+As(V)) determined by chemical extraction followed by HPLC-ICPMS analysis vs. LCF-XANES data. Examples of LCF reconstruction of XANES signals are given in Figure S5 using the reference compounds presented in Figure S1 (Supplementary Information). 


\section{2.b. Speciation of arsenic in orthophosphoric acid extracts}

\section{$i$ - Stability of arsenic speciation in the extracts}

The stability of As oxidation state in orthophosphoric extracts throughout time was assessed to consider a possible storage delay prior to analysis by HPLC-ICP-MS. No significant conversion of As(III) into As(V) species was observed after 7 and 35 days for both undiluted extracts and diluted extracts, indicating that speciation analysis can be performed up to one month after the extraction (Figure 2). Arsenic species distribution was preserved despite the presence of high amount of dissolved Fe(III) in the extracts, probably due to the inhibition of Fe-mediated photooxidation processes ensured by a storage under dark conditions ${ }^{31}$ and the complexation of dissolved Fe(III) with phosphate ions. ${ }^{32}$

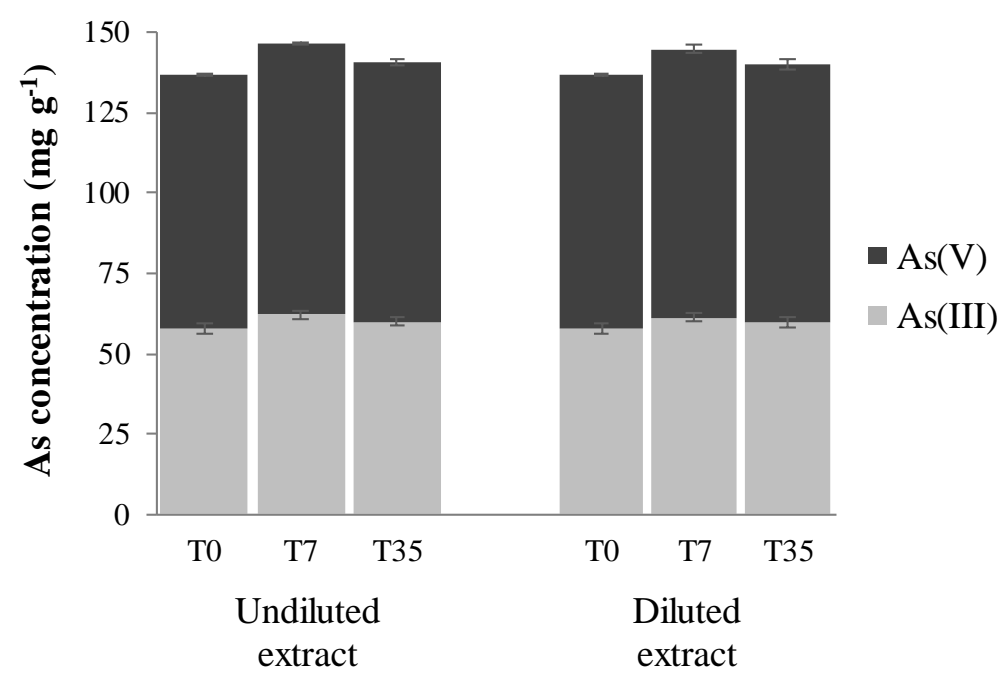

Figure 2: As(III) and As(V) concentrations $\left(\mathrm{mg} \mathrm{g}^{-1}\right)$ in $\mathrm{F} 5$ sample determined by analysing undiluted extracts $(n=3)$ and diluted extracts (stabilized by a 100-times dilution in $1 \% \mathrm{v} / \mathrm{v}$ acetic acid-EDT A solution, $\mathrm{n}=3$ ), the day of the extraction (T0), after 7 days (T7) and 35 days (T35) of storage (at $4{ }^{\circ} \mathrm{C}$ under darkness).

\section{ii- Speciation of arsenic in AMD-precipitate samples}

Arsenic(III) was observed in the orthophosphoric extracts from all the studied AMD-precipitate samples except for pure synthetic As(V)-schwertmannite (Figure 1b). The proportion of As(III) compared to total As extracted (As(III)/ $/ \mathrm{As}$ ) ranged from 6 to $65 \%$ in field AMD-precipitates, from 20 to $81 \%$ in laboratory AMD-precipitates and from 0 to $99 \%$ in $\operatorname{As}(\mathrm{III})-/ \mathrm{As}(\mathrm{V})$ schwertmannite mixtures (Supplementary Information, Table S2). Arsenic(III)/ $\Sigma$ As ratios obtained from the chemical extraction matched well with As(III) proportion values from the LCF-XANES analyses $\left(R^{2}=0.958\right.$, Figure $\left.1 \mathrm{~b}\right)$ and considering uncertainties of both methods (Supplementary Information, Table S2), no significant differences were observed for most 


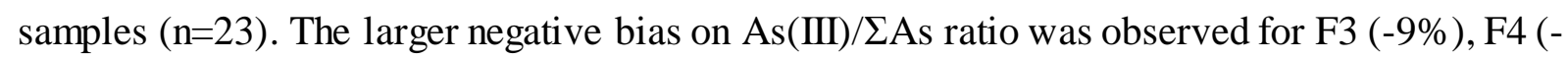
$12 \%)$ and F5 (-10\%) samples, whereas positive bias (i.e. an As(III) proportion determined by chemical extraction higher than XANES data) were observed for three laboratory samples: 2A$\mathrm{G} 2(+12 \%), 2 \mathrm{~A}-\mathrm{G} 3(+6 \%)$ and $1 \mathrm{~B}-\mathrm{G} 2(+7 \%)$. It should be noted that there was no relation between the bias value and As extraction yield, As concentration, As/Fe ratio or mineralogical composition.

In addition, the chemical extraction procedure was applied to the field AMD-precipitate sample F7 after doping with an As(III) standard; the spiked As(III) was completely recovered (102\%) without conversion to As(V) confirming that As(III) oxidation does not occur during the extraction step. As the samples F3 and F4 were collected at the Carnoulès mine in $2000{ }^{5}$, a partial oxidation of As(III) upon ageing could explain the lower As(III) proportion observed with the chemical extraction method rather than As(III) oxidation during the procedure. Otherwise, as only $15 \mathrm{mg}$ of sample are used for XANES analysis, small discrepancies could possibly be observed due to sample heterogeneity.

Altogether, the results indicated that As oxidation state of AMD precipitates was successfully preserved during and after the extraction step while several studies dealing with As speciation in soils and sediments reported a conversion of As(III) into As(V) during orthophosphoric acid extraction of As(III)-spiked samples. ${ }^{17,20,21,24}$ This conversion was assigned to the co-extraction of some soil and sediment constituents, such as Mn and Fe, which could either oxidise As(III) or catalyse its oxidation in the presence of dissolved oxygen. ${ }^{21,25}$ In particular, Giral et al. ${ }^{25}$ observed that the soil content in Mn oxides had a major influence on As(III) oxidation during the extraction. In the present study, the low Mn content (1-20 $\left.\mu \mathrm{g} \mathrm{g}^{-1}\right)$ of the AMD precipitates would exclude such effect and as mentioned earlier, Fe(III) complexation with phosphate ions and dark storage may have inhibited the oxidation of $\mathrm{As}(\mathrm{III})$ into $\mathrm{As}(\mathrm{V})$ by reactive species produced from $\mathrm{Fe}$ (III) hydrolysis. Finally, the high As/Fe ratios in the solids might contribute to inhibit As(III) oxidation since a decrease in As(III) oxidation rate has already been evidenced with increasing As/Fe ratio during abiotic experiments dealing with As(III) oxidation in acidic Fe(III)-rich waters. ${ }^{31}$

\subsection{Limitations of the proposed orthophosphoric acid extraction method}

The AMD-precipitate samples exhibited high As content due to high dissolved As levels that characterize AMD waters at the Carnoulès mine., ${ }^{4,13}$ Application of the proposed method to 
environmental samples in which As would be present at trace levels could imply a lower dilution of orthophosphoric acid extracts than in the present study, where dilution factors ranged from 2000 to 10,000. Previous studies showed that an orthophosphoric acid concentration up to $0.3 \mathrm{M}$ did not significantly influence the chromatograms ${ }^{20,21}$, thus allowing a 4-fold minimal dilution following the proposed $1 \mathrm{M}$ orthophosphoric acid extraction. Such a low dilution may be unappropriate due to the high $\mathrm{Fe}$ content of the extracts. However, considering the low detection limit for As(III) and As(V) species in HPLC-ICP-MS and the lowest dilution (2000fold) used in the present study, the method is applicable to AMD-precipitates with As(III) and As(V) concentrations as low as $0.1 \mathrm{mg} \mathrm{g}^{-1}$ and $0.5 \mathrm{mg} \mathrm{g}^{-1}$ respectively, without any disturbance of the chromatographic separation due to matrix effect.

Additional improvement of the proposed method could be done by analysing As(III) and As(V) species in the orthophosphoric extract using a simpler and more cost-effective method such as HG-AFS (hydride generation-atomic fluorescence spectrometry). ${ }^{33,34}$

\section{Conclusions}

The application of a $1 \mathrm{M}$ orthophosphoric acid extraction $\left(95^{\circ} \mathrm{C}, 1 \mathrm{~h}\right)$ followed by HPLC-ICPMS analysis is a suitable method to determine As speciation in Fe-rich precipitates originating from AMD as well as in AMD-remediation devices. Total arsenic was fully recovered $(99 \pm 10 \%)$ from all the studied As-bearing phases consisted of amorphous Fe phases, schwertmannite and tooeleite which are representative of Fe precipitates forming in AMD. The comparison of speciation results from orthophosphoric acid extraction and HPLC-ICP-MS analysis with reference data from LCF-XANES analysis proves that the proposed method successfully preserved As(III) and As(V) species distribution during the entire procedure. Moreover, at least a one-month delay is allowed between the extraction step and the speciation analysis of the extracts. Finally, the proposed method can be easily implemented and can consequently be recommended as a routine procedure for the determination of As oxidation state in As/Fe-rich precipitates from AMD-impacted streams and remediation devices.

\section{Aknowledgements}

This study was supported by the French National Research Agency ANR through the IngECOST-DMA project(ANR-13-ECOT-0009). The authors thank Marie-Christine Gujda for having kindly provided the TOC picture of the Reigous Creek. ICP-MS and HPLC-ICP-MS analysis were carried out at the AETE Platform (OSU OREME, Université de Montpellier). 


\section{6. $\quad$ References}

1 C. Casiot, M. Leblanc, O. Bruneel, J.-C. Personné, K. Koffi and F. Elbaz-Poulichet, Aquat. Geochemistry, 2003, 9, 273-290.

2 H. Cheng, Y. Hu, J. Luo, B. Xu and J. Zhao, J. Hazard. Mater., 2009, 165, 13-26.

3 A. M. Sarmiento, J. M. Nieto, C. Casiot, F. Elbaz-Poulichet and M. Egal, Environ. Pollut., 2009, 157, 1202-1209.

4 M. Egal, C. Casiot, G. Morin, F. Elbaz-Poulichet, M.-A. Cordier and O. Bruneel, Appl. Geochemistry, 2010, 25, 1949-1957.

5 G. Morin, F. Juillot, C. Casiot, O. Bruneel, J.-C. Personné, F. Elbaz-Poulichet, M. Leblanc, P. Ildefonse and G. Calas, Environ. Sci. Technol., 2003, 37, 1705-1712.

6 A. Adra, G. Morin, G. Ona-Nguema and J. Brest, Appl. Geochemistry, 2016, 64, 2-9.

7 M. P. Asta, C. Ayora, G. Román-Ross, J. Cama, P. Acero, A. G. Gault, J. M. Charnock and F. Bardelli, Chem. Geol., 2010, 271, 1-12.

8 G. Morin and G. Calas, Elements, 2006, 2, 97-101.

9 A. G. Gault, D. R. Cooke, A. T. Townsend, J. M. Charnock and D. A. Polya, Sci. Total Environ., 2005, 345, 219-28.

10 L. Carlson, J. M. Bigham, U. Schwertmann, A. Kyek and F. Wagner, Environ. Sci. Technol., 2002, 36, 1712-1719.

11 F. Maillot, G. Morin, F. Juillot, O. Bruneel, C. Casiot, G. Ona-Nguema, Y. Wang, S. Lebrun, E. Aubry, G. Vlaic and G. E. Brown, Geochim. Cosmochim. Acta, 2013, 104, $310-329$.

12 K. Benzerara, G. Morin, T. H. Yoon, J. Miot, T. Tyliszczak, C. Casiot, O. Bruneel, F. Farges and G. E. Brown, Geochim. Cosmochim. Acta, 2008, 72, 3949-3963.

13 C. Casiot, S. Lebrun, G. Morin, O. Bruneel, J. C. Personné and F. Elbaz-Poulichet, Sci. Total Environ., 2005, 347, 122-130.

14 M. J. La Force, C. M. Hansel and S. Fendorf, Environ. Sci. Technol., 2000, 34, 39373943.

15 V. J. Ritchie, A. G. Ilgen, S. H. Mueller, T. P. Trainor and R. J. Goldfarb, Chem. Geol., 2013, 335, 172-188.

16 J. L. Gomez-Ariza, D. Sanchez-Rodas and I. Giraldez, J. Anal. At. Spectrom., 1998, 13, $1375-1379$.

17 M. Montperrus, Y. Bohari, M. Bueno, A. Astruc and M. Astruc, Appl. Organomet. Chem., 2002, 16, 347-354.

18 M. J. Ruiz-Chancho, R. Sabé, J. F. López-Sánchez, R. Rubio and P. Thomas, Microchim. Acta, 2005, 151, 241-248.

19 M. Ruiz-Chancho, J. Lopez-Sanchez and R. Rubio, Anal. Bioanal Chem, 2007, 387, 
$627-635$.

20 P. Thomas, J. K. Finnie and J. G. Williams, J. Anal. At. Spectrom., 1997, 12, 1367-1372.

21 M. V. Gallardo, Y. Bohari, A. Astruc, M. Potin-Gautier and M. Astruc, Anal. Chim. Acta, 2001, 441, 257-268.

22 S. Garcia-Manyes, Talanta, 2002, 58, 97-109.

23 M. M. Rahman, Z. Chen and R. Naidu, Environ. Geochem. Health, 2009, 31, 93-102.

24 C. Demesmay and M. Olle, Fresenius. J. Anal. Chem., 1997, 357, 1116-1121.

25 M. Giral, G. J.Zagury, L. Deschênes and J.-P. Blouin, Environ. Pollut., 2010, 158, 18901898.

26 J. H. Huang and R. Kretzschmar, Anal. Chem., 2010, 82, 5534-5540.

27 G. Samanta and D. A. Clifford, Environ. Sci. Technol., 2005, 39, 8877-8882.

28 R. Barham, J. Mater. Res., 1997, 12, 2751-2758.

29 M. Héry, C. Casiot, E. Resongles, Z. Gallice, O. Bruneel, A. Desoeuvre and S. Delpoux, Environ. Chem., 2014, 11, 514.

30 M. Egal, C. Casiot, G. Morin, M. Parmentier, O. Bruneel, S. Lebrun and F. ElbazPoulichet, Chem. Geol., 2009, 265, 432-441.

31 M. P. Asta, D. Nordstrom and R. McCleskey, Appl. Geochemistry, 2012, 27, 281-291.

32 B. Daus, J. Mattusch, R. Wennrich and H. Weiss, Talanta, 2002, 58, 57-65.

33 A. Gonzalvez, M. L. Cervera, S. Armenta and M. de la Guardia, Anal. Chim. Acta, 2009, 636, $129-157$.

34 M. N. M. Reyes, M. L. Cervera, R. C. Campos and M. de la Guardia, Talanta, 2008, 75, 811-816. 


\section{Supplementary Information}

Routine determination of inorganic arsenic speciation in precipitates from acid mine drainage using orthophosphoric acid extraction followed by HPLC-ICP-MS

Resongles E. ${ }^{a}$, Le Pape P. ${ }^{b}$, Fernandez-Rojo L.., Morin G. ${ }^{b}$, Delpoux S. ${ }^{a}$, Brest J. ${ }^{b}$, Guo S. ${ }^{b}$, Casiot C. ${ }^{a}$

a HydroSciences Montpellier UMR 5569, Université Montpellier, CNRS, IRD, CC 57, 163 Rue Auguste Broussonet, F-34090 Montpellier, France.

b Sorbonne Universités - Institut de Minéralogie, de Physique des Matériaux et de Cosmochimie (IMPMC), UMR UPMC-CNRS-IRD-MNHN 7590, UPMC Université Paris VI, 4 place Jussieu, 75252 Paris cedex 05, France.

*Corresponding author: corinne.casiot-marouani@umontpellier.fr 


\section{1. $\quad$ SYNTHESIS OF AS(III)- AND AS(V)-SORBED SCHWERTMANNITE}

Prior to As sorption, schwertmannite was synthesized according to Barham (1997). A solution of $\mathrm{FeSO}_{4}$ $(0.1 \mathrm{M})$ was adjusted to $\mathrm{pH} 2.5$ with $\mathrm{H}_{2} \mathrm{SO}_{4}$ in an anaerobic chamber. The solution was then removed from the anaerobic chamber and oxidized using an excess of $\mathrm{H}_{2} \mathrm{O}_{2}$ while stirring and heating at $70{ }^{\circ} \mathrm{C}$. After 2 hours, the solid phase was recovered by centrifugation and dried under vacuum. Sorption of $\mathrm{As}(\mathrm{III})$ or $\mathrm{As}(\mathrm{V})$ onto synthetic schwertmannite was performed under anoxic conditions by adding appropriate amounts of a solution of $\mathrm{As}(\mathrm{III}) 0.1 \mathrm{M}\left(\mathrm{NaAsO}_{2}\right)$ or $\mathrm{As}(\mathrm{V}) 0.1 \mathrm{M}\left(\mathrm{Na}_{2} \mathrm{HAsO}_{4} \cdot 7 \mathrm{H}_{2} \mathrm{O}\right)$ to obtain solid containing ratio of $0.05 \mathrm{As} / \mathrm{Fe}(\mathrm{mol} / \mathrm{mol})$ according to Maillot et al. (2013). Solids were then centrifuged and dried under vacuum in the anaerobic chamber.

\section{Reference}

Barham R. J. (1997) Schwertmannite: a unique mineral, contains a replaceable ligand, transforms to jarosite, hematite, and/or basic iron sulfate. J. Mater. Res. 12(10), 2751-2758.

\section{DETERMINATION OF TOTAL ARSENIC AND IRON CONCENTRATIONS}

Total As and Fe concentrations were determined using an aqua regia digestion followed by ICP-MS analysis. Digestion of solid samples was carried out in a class 10,000 clean room. All material was acidcleaned before use. About $0.1 \mathrm{~g}$ of milled sample was digested in PTFE reactor on hot plate using (1) 3 $\mathrm{mL}$ of $35 \% \mathrm{H}_{2} \mathrm{O}_{2}$ during $16 \mathrm{~h}$ at room temperature followed by $24 \mathrm{~h}$ at $95{ }^{\circ} \mathrm{C}$ and (2) a $1: 3 \mathrm{~mL}$ concentrated $\mathrm{HNO}_{3}-\mathrm{HCl}$ mixture (aqua regia) during $24 \mathrm{~h}$ at $95{ }^{\circ} \mathrm{C}$. Samples were allowed to cool to room temperature and evaporated to dryness at $65{ }^{\circ} \mathrm{C}$ between the two steps and at the end of the procedure. Then, samples were brought to $30 \mathrm{~mL}$ using $3 \mathrm{~mL} \mathrm{HNO}_{3}$ and double deionized water. Finally, samples were filtered to remove possible residues using a polypropylene syringe and a $0.22 \mu \mathrm{m}$ cellulose acetate syringe filter previously rinsed with $10 \% \mathrm{v} / \mathrm{v} \mathrm{HNO}_{3}$. Method blank and certified reference material digestion (Stream sediments LGC6189 from United Kingdom Accreditation Service) were performed.

Total As and Fe concentrations were determined after an adequate dilution using an ICP-MS, iCAP Q (ThermoFisher Scientific) equipped with KED (Kinetic Energy Discrimination Technology). A $10 \mu \mathrm{g} \mathrm{L}^{-1}$ Ge solution in $1 \% \mathrm{HNO}_{3}(\mathrm{v} / \mathrm{v})$ was injected on-line as internal standard. The quality of analytical methods was checked by analysing international certified reference waters (SLRS-5, NIST1643e); results ranged within $10 \%$ relative to the certified values. Analytical error (relative standard deviation) was better than 5\%. Finally, accuracy was within $8 \%$ of the As certified value for the sediment reference material (LGC6189) and the procedural blank represents less than $0.1 \%$ of As and Fe concentration measured in samples. 


\section{COMPARISON OF EXTRACTION METHODS}

\subsection{Experimental section}

In a first stage, in addition to the $1 \mathrm{M} \mathrm{H}_{3} \mathrm{PO}_{4}$ extraction method describes in section 2.4.a of the main paper (hereafter referred to as "protocol D"), the three following extraction protocols have been tested using $100 \mathrm{mg}$ of samples. For that, F5 and F7 samples were selected because they contain both As(III) and $\mathrm{As}(\mathrm{V})$ species (As(III)/ $/ \mathrm{As}$ of 53 and $41 \%$, respectively) and As is associated with crystallized phases from which As may be more difficult to extract than from amorphous phases.

Protocol A- Extraction with $15 \mathrm{~mL}$ of $1 \mathrm{M} \mathrm{H}_{3} \mathrm{PO}_{4}$ (VWR Chemicals, analytical grade, 85\%) in an acid-cleaned Pyrex tube. The sample was maintained at $60 \mathrm{~W}$ during $10 \mathrm{~min}$ using a microwave system (Discover SP-D Plus, CEM®) (Rahman et al., 2009).

Protocol B- Extraction with $15 \mathrm{~mL}$ of $1 \mathrm{M} \mathrm{H}_{3} \mathrm{PO}_{4}$ (VWR Chemicals, analytical grade, 85\%) $+0.5 \mathrm{M}$ ascorbic acid (Sigma-Aldrich, 99.7-100.5 \%) in an acid-cleaned Pyrex tube. The sample was maintained at $60 \mathrm{~W}$ during $10 \mathrm{~min}$ using a microwave system (Discover SP-D Plus, CEM®) (Giral et al., 2010).

Protocol C- Extraction with $2 \mathrm{~mL}$ of $4 \mathrm{M} \mathrm{HCl}$ (Merck, Suprapur, 30\%) $+10 \%$ acetic acid (VWR Chemicals, analytical grade, 100\%) in a polypropylene tube. The sample was heated at $95{ }^{\circ} \mathrm{C}$ during $1 \mathrm{~h}$ on a hot plate (Huang and Kretzschmar, 2010).

After the extraction step, samples were allowed to cool to room temperature and were filtered using a polypropylene syringe and a cellulose acetate syringe filter $(0.22 \mu \mathrm{m})$. The first drops of the filtered extract were not kept allowing the syringe filter to be rinsed out. Extracts were diluted (10,000-fold for method A and B and 100,000-fold for method C) with an acid acetic-EDTA solution (1\% v/v) and analysed by HPLC-ICP-MS as described in the section 2.4.b of the main paper.

\section{References}

Giral, M., Zagury, G.J., Deschênes, L., Blouin, J.-P., 2010. Comparison of four extraction procedures to assess arsenate and arsenite species in contaminated soils. Environ. Pollut. 158, 1890-1898. doi:10.1016/j.envpol.2009.10.041

Huang, J.H., Kretzschmar, R., 2010. Sequential extraction method for speciation of arsenate and arsenite in mineral soils. Anal. Chem. 82, 5534-5540. doi:10.1021/ac100415b

Rahman, M.M., Chen, Z., Naidu, R., 2009. Extraction of arsenic species in soils using microwave-assisted extraction detected by ion chromatography coupled to inductively coupled plasma mass spectrometry. Environ. Geochem. Health 31 Suppl 1,93-102. doi:10.1007/s10653-008-9227-0 


\subsection{Results}

Arsenic was almost completely extracted (Figure S2a) whatever the extraction method used, with extraction yield averaging $77 \pm 3 \%$ for $\mathrm{F} 7$ and $100 \pm 7 \%$ for F5 samples.

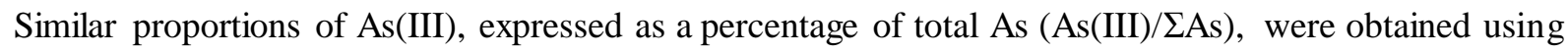
the extraction methods $\mathrm{A}, \mathrm{C}$ and $\mathrm{D}$ for both samples $(\mathrm{As}(\mathrm{III}) / \Sigma \mathrm{As}=46 \pm 1 \%$ for $\mathrm{F} 7$ sample and $\mathrm{As}(\mathrm{III}) / \Sigma \mathrm{As}=41 \pm 1 \%$ for F5 sample, Figure S2b). In contrast, the procedure B $\left(1 \mathrm{M} \mathrm{H}_{3} \mathrm{PO}_{4}+0.5 \mathrm{M}\right.$ ascorbic acid under microwaves) gave a higher As(III) proportion in $\mathrm{F} 7$ sample, with As(III)/ $\Sigma$ As ratio of $89 \%$, which implied either reduction of $\mathrm{As}(\mathrm{V})$ into $\mathrm{As}(\mathrm{III})$ during this procedure or As(III) oxidation with the other protocols. The latter assumption was inconsistent considering XANES data and suggest that a reduction of $\mathrm{As}(\mathrm{V})$ occurred during the extraction step. An $\mathrm{As}(\mathrm{III}) / \Sigma \mathrm{As}$ ratio of $86 \%$ was obtained for $\mathrm{F} 7$ sample spiked with $\mathrm{As}(\mathrm{V})$ standard before applying the extraction procedure B confirming that $\operatorname{As}(\mathrm{V})$ was partially reduced during the extraction step.

On the basis of these tests, the method B was not tested further. Moreover, method D was preferred to the methods $\mathrm{A}$ and $\mathrm{C}$. Indeed, $\mathrm{H}_{3} \mathrm{PO}_{4}$ concentration up to $0.3 \mathrm{M}$ did not disturb chromatographic separation of As(III) and As(V) species (Gallardo et al., 2001), allowing a minimal 2000-times dilution factor for orthophosphoric acid extracts to be analysed, which remains compatible with the analysis of lower concentrated samples (see the section 3.3 of the main paper for details). Conversely, high chloride concentration in $\mathrm{HCl}$ extracts may generate polyatomic interferences during HPLC-ICP-MS analysis (Rahman et al., 2009). Finally, standard hot plate heating in procedure D was preferred to microwaveassisted extraction in procedure A for its easiest and cheapest implementation. 


\section{ARSENIC SPECIATION BY ORTHOPHOSPHORIC ACID EXTRACTION AND HPLC-ICP-MS}

ANALYSIS: UNCERTAINTY CALCULATION

The reproducibility of the orthophosphoric acid extraction method was determined through measuring replicate AMD-precipitate extracts for selected field samples (F5, F6 and F7) and laboratory samples (1A-G4 and 2A-G3) (Table S1). The relative standard deviations (RSDs) ranged from 1 to $6 \%$ for As(III) concentration and from 2 to $8 \%$ for $\mathrm{As}(\mathrm{V})$ concentration.

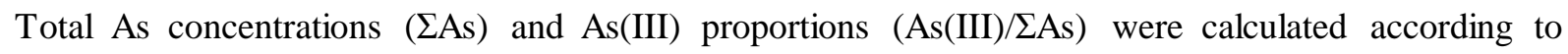
equations 1 and 2, respectively. The uncertainties of total As concentrations and As(III) proportions were assessed from an error propagation calculation on the basis of the standard deviation $(\sigma)$ and average values obtained for $\mathrm{As}(\mathrm{III})$ and $\mathrm{As}(\mathrm{V})$ concentrations (equations 3 and 4, respectively). The relative standard deviations (RSDs) were $2-6 \%$ for total As concentration and 3-11\% for As(III) proportion (Table S1).

Equation 1: $\quad \Sigma A s=A s(I I I)+A s(V)$

Equation 2: $\quad \frac{A s(I I I)}{\Sigma A s}=\left(\frac{A s(I I I)}{A s(I I I)+A s(V)}\right)$

Equation 3: $\quad \sigma[\Sigma A s]=\sigma[A s(I I I)]+\sigma[A s(V)]$

Equation 4: $\quad \sigma\left[\frac{A s(I I I)}{\Sigma A s}\right]=\left[\left(\frac{\sigma[A s(I I I)]}{A s(I I I)_{\text {avg }}}\right)+\left(\frac{\sigma\left[\sum A s\right]}{\Sigma A s_{\text {avg }}}\right)\right] \times\left(\frac{A s(I I I)}{\Sigma A s}\right)_{\text {avg }}$ 


\section{5. $\quad$ SUPPPORTING INFORMATION - TABLES AND FIGURES}

Table S1: As(III) and As(V) concentrations measured in replicate extracts and corresponding total As

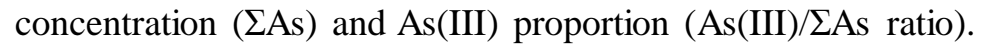

\section{$\operatorname{As}(\mathrm{III})\left(\mathrm{mg} \mathrm{g}^{-1}\right) \quad \operatorname{As}(\mathrm{V})\left(\mathrm{mg} \mathrm{g}^{-1}\right) \quad \boldsymbol{\Sigma A s}\left(\mathrm{mg} \mathrm{g}^{-1}\right) \quad \operatorname{As}(\mathrm{III}) / \Sigma \mathrm{As}(\%)$}

\begin{tabular}{|c|c|c|c|c|}
\hline \multicolumn{5}{|l|}{ F5 sample } \\
\hline$\# 1$ & 60 & 90 & 149 & 40 \\
\hline$\# 2$ & 61 & 91 & 152 & 40 \\
\hline$\# 3$ & 57 & 79 & 136 & 42 \\
\hline$\# 4$ & 59 & 79 & 138 & 43 \\
\hline \#5 & 58 & 79 & 137 & 42 \\
\hline Average & 59 & 84 & 142 & 41 \\
\hline Standard deviation & 2 & 6 & 8 & 4 \\
\hline$R S D(\%)$ & 3 & 8 & 6 & 9 \\
\hline \multicolumn{5}{|l|}{ F6 sample } \\
\hline$\# 1$ & 89 & 47 & 136 & 65 \\
\hline$\# 2$ & 85 & 46 & 131 & 65 \\
\hline$\# 3$ & 87 & 48 & 135 & 65 \\
\hline Average & 87 & 47 & 134 & 65 \\
\hline Standard deviation & 2 & 1 & 3 & 3 \\
\hline$R S D(\%)$ & 2 & 2 & 2 & 4 \\
\hline \multicolumn{5}{|l|}{ F7 sample } \\
\hline$\# 1$ & 63 & 66 & 129 & 49 \\
\hline$\# 2$ & 56 & 70 & 126 & 45 \\
\hline \#3 & 58 & 72 & 130 & 45 \\
\hline Average & 59 & 69 & 128 & 46 \\
\hline Standard deviation & 3 & 3 & 7 & 5 \\
\hline$R S D(\%)$ & 6 & 4 & 5 & 11 \\
\hline \multicolumn{5}{|l|}{ 1A-G4 sample } \\
\hline$\# 1$ & 15 & 66 & 82 & 19 \\
\hline$\# 2$ & 16 & 65 & 82 & 20 \\
\hline \#3 & 16 & 65 & 81 & 20 \\
\hline \#4 & 17 & 61 & 77 & 22 \\
\hline Average & 16 & 64 & 80 & 20 \\
\hline Standard deviation & 1 & 2 & 3 & 2 \\
\hline$R S D(\%)$ & 4 & 4 & 4 & 8 \\
\hline \multicolumn{5}{|l|}{ 2A-G3 sample } \\
\hline$\# 1$ & 35 & 63 & 98 & 35 \\
\hline$\# 2$ & 35 & 60 & 94 & 37 \\
\hline \#3 & 35 & 60 & 96 & 37 \\
\hline$\# 4$ & 35 & 60 & 95 & 37 \\
\hline Average & 35 & 61 & 96 & 36 \\
\hline Standard deviation & 0 & 2 & 2 & 1 \\
\hline$R S D(\%)$ & 1 & 3 & 2 & 3 \\
\hline
\end{tabular}


Table S2: Total arsenic concentration and As(III) proportion determined by total digestion-ICP-MS and XANES analysis and by orthophosphoric acid extraction-HPLC-ICP-MS.

\begin{tabular}{|c|c|c|c|c|c|c|c|c|}
\hline \multirow{3}{*}{ Sample } & \multicolumn{4}{|c|}{ Total arsenic concentration (mg $\left.\mathbf{g}^{-1}\right)$} & \multicolumn{4}{|c|}{ Arsenic(III) proportion (\%) } \\
\hline & \multicolumn{2}{|c|}{ Total digestion } & \multicolumn{2}{|c|}{$\begin{array}{l}\text { Orthophosphoric } \\
\text { acid extraction }\end{array}$} & \multicolumn{2}{|c|}{ XANES } & \multicolumn{2}{|c|}{$\begin{array}{c}\text { Orthophosphoric } \\
\text { acid extraction }\end{array}$} \\
\hline & Average & SD & Average & SD & Average & 3SD & Average & SD \\
\hline \multicolumn{9}{|c|}{ AMD-precipitates (field samples) } \\
\hline $\mathrm{F} 1(\mathrm{~S} 32 \mathrm{~F} 00)^{\mathrm{a}}$ & $220^{\mathrm{b}}$ & 18 & 220 & 12 & 7 & 3 & 6 & 1 \\
\hline F2 (unpubl.) & $120^{\mathrm{b}}$ & 10 & 124 & 7 & 14 & 3 & 11 & 1 \\
\hline $\mathrm{F} 3(\mathrm{~S} 30 \mathrm{~F} 00)^{\mathrm{a}}$ & $210^{\mathrm{b}}$ & 17 & 232 & 13 & 58 & 3 & 48 & 5 \\
\hline $\mathrm{F} 4(\operatorname{Cs} 12)^{\mathrm{a}}$ & $240^{\mathrm{b}}$ & 19 & 267 & 15 & 72 & 3 & 59 & 6 \\
\hline F5 & 145 & 12 & 142 & 8 & 53 & 5 & 41 & 4 \\
\hline F6 & 138 & 11 & 134 & 3 & 72 & 6 & 65 & 3 \\
\hline F7 & 157 & 13 & 128 & 7 & 41 & 5 & 46 & 5 \\
\hline \multicolumn{9}{|c|}{ AMD-precipitates (laboratory samples) } \\
\hline $0-\mathrm{G} 1$ & 76 & 6 & 87 & 5 & 40 & 3 & 37 & 4 \\
\hline $0-\mathrm{G} 2$ & 66 & 5 & 64 & 4 & 71 & 3 & 63 & 7 \\
\hline $1 \mathrm{~A}-\mathrm{G} 4$ & 84 & 7 & 80 & 3 & 16 & 2 & 20 & 2 \\
\hline 1B-G1 & 83 & 7 & 76 & 4 & 22 & 2 & 25 & 3 \\
\hline 1B-G2 & 81 & 6 & 79 & 4 & 25 & 2 & 31 & 3 \\
\hline 2A-G1 & 75 & 6 & 71 & 4 & 46 & 2 & 53 & 6 \\
\hline $2 \mathrm{~A}-\mathrm{G} 2$ & 68 & 5 & 62 & 4 & 54 & 2 & 65 & 7 \\
\hline $2 \mathrm{~A}-\mathrm{G} 3$ & 95 & 8 & 96 & 2 & 31 & 2 & 36 & 1 \\
\hline 2A-G4 & 70 & 6 & 68 & 4 & 50 & 2 & 56 & 6 \\
\hline $3 \mathrm{~A}-\mathrm{G} 1$ & 97 & 8 & 89 & 5 & 66 & 2 & 65 & 7 \\
\hline $3 \mathrm{~A}-\mathrm{G} 2$ & 79 & 6 & 76 & 4 & 76 & 2 & 75 & 8 \\
\hline $3 \mathrm{~A}-\mathrm{G} 3$ & 71 & 6 & 69 & 4 & 80 & 2 & 80 & 9 \\
\hline $3 \mathrm{~A}-\mathrm{G} 4$ & 73 & 6 & 64 & 4 & 80 & 2 & 78 & 9 \\
\hline 3B-G1 & 72 & 6 & 70 & 4 & 77 & 2 & 77 & 9 \\
\hline $3 \mathrm{~B}-\mathrm{G} 2$ & 62 & 5 & 59 & 3 & 80 & 2 & 81 & 9 \\
\hline 3B-G3 & 59 & 5 & 42 & 2 & 78 & 2 & 78 & 9 \\
\hline 3B-G4 & & & 54 & 3 & 74 & 2 & 73 & 8 \\
\hline \multicolumn{9}{|c|}{ Synthetic As(III)-/As(V)-schwertmannite mixtures } \\
\hline $100 / 0^{c}$ & 48 & 4 & 46 & 3 & 100 & 0 & 99 & 11 \\
\hline $90 / 10^{c}$ & 45 & 4 & 45 & 3 & 88 & 2 & 85 & 9 \\
\hline $50 / 50^{c}$ & 37 & 3 & 40 & 2 & 43 & 2 & 41 & 5 \\
\hline $10 / 90^{c}$ & 32 & 3 & 38 & 2 & 8 & 2 & 7 & 1 \\
\hline $0 / 100^{c}$ & 31 & 2 & 36 & 2 & 0 & 0 & 0 & 0 \\
\hline
\end{tabular}

${ }^{\text {a }}$ Sample reference in Morin et al. (2003)

${ }^{\mathrm{b}}$ Data obtained by electron microprobe analysis (Morin et al. 2003)

c Percentage of As(III)-Schwertmannite/As(V)-Schwertmannite 


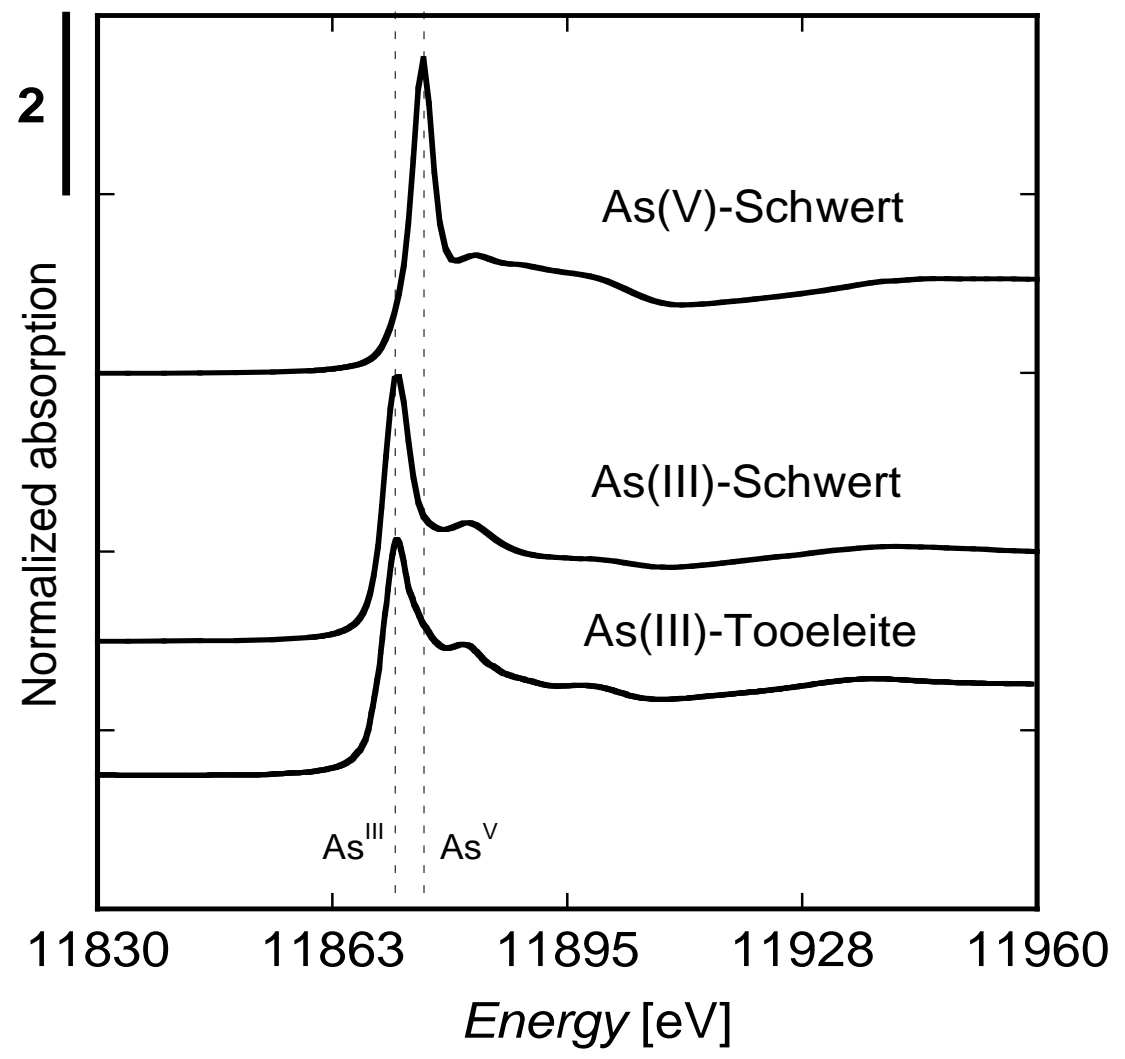

Figure S1: XANES spectra of reference compounds used for linear combination fitting procedure applied to experimental XANES spectra of AMD samples. 

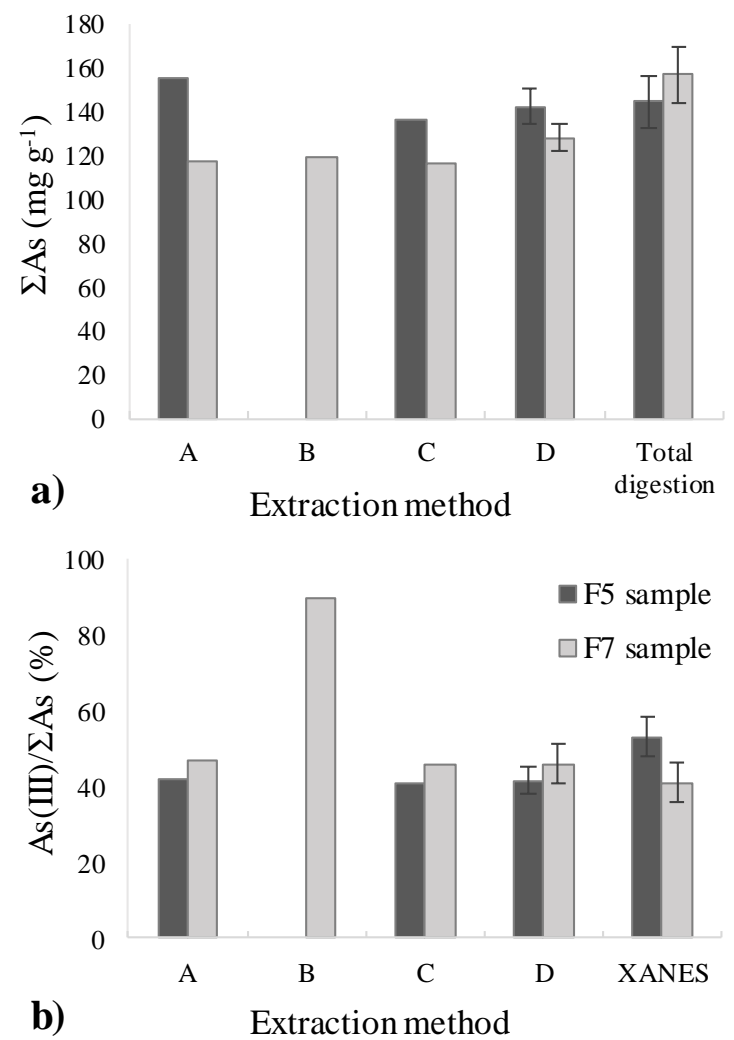

Figure S2: a) Sum of $\mathrm{As}(\mathrm{III})$ and $\mathrm{As}(\mathrm{V})$ concentrations ( $\Sigma \mathrm{As}$ in $\left.\mathrm{mg} \mathrm{g}^{-1}\right)$ and b) proportion of $\mathrm{As}(\mathrm{III})$ (expressed as a percentage of total As: As(III)/ $\Sigma$ As) determined in F5 and F7 samples using the four different extraction methods $\mathrm{A}, \mathrm{B}, \mathrm{C}$ and $\mathrm{D}$; and comparison with (a) total digestion and (b) XANES data. 


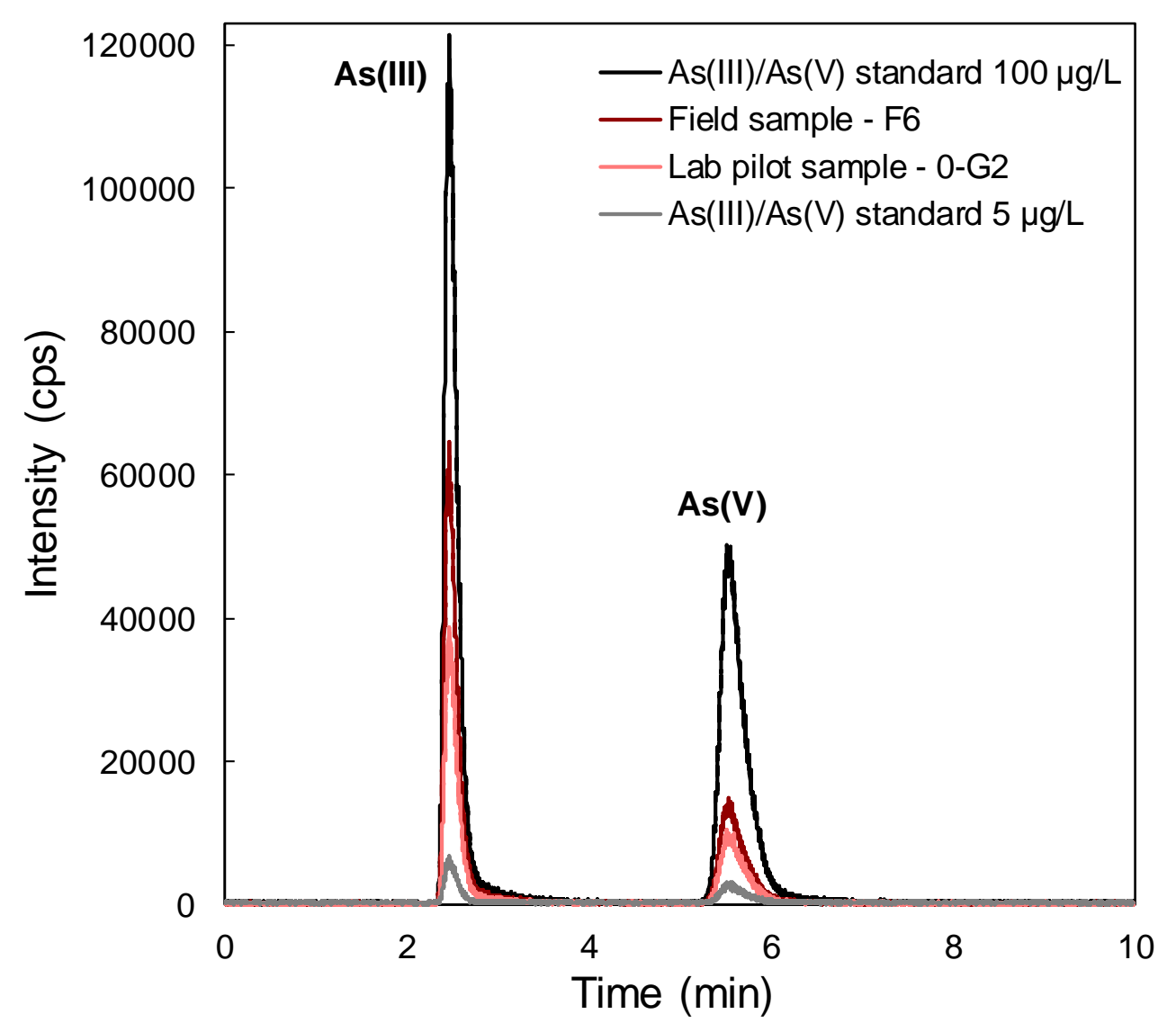

Figure S3: Examples of HPLC-chromatograms of As(III) and As(V) species obtained for selected samples (F6 and 0-G2) and calibration standard solutions (5 and $\left.100 \mu \mathrm{g} \mathrm{L}^{-1}\right)$ using an anion-exchange PRP-X100 column $(250 \times 4 \mathrm{~mm})$ and ammonium phosphate buffer $(\mathrm{pH} 8.0,30 \mathrm{mM})$. 


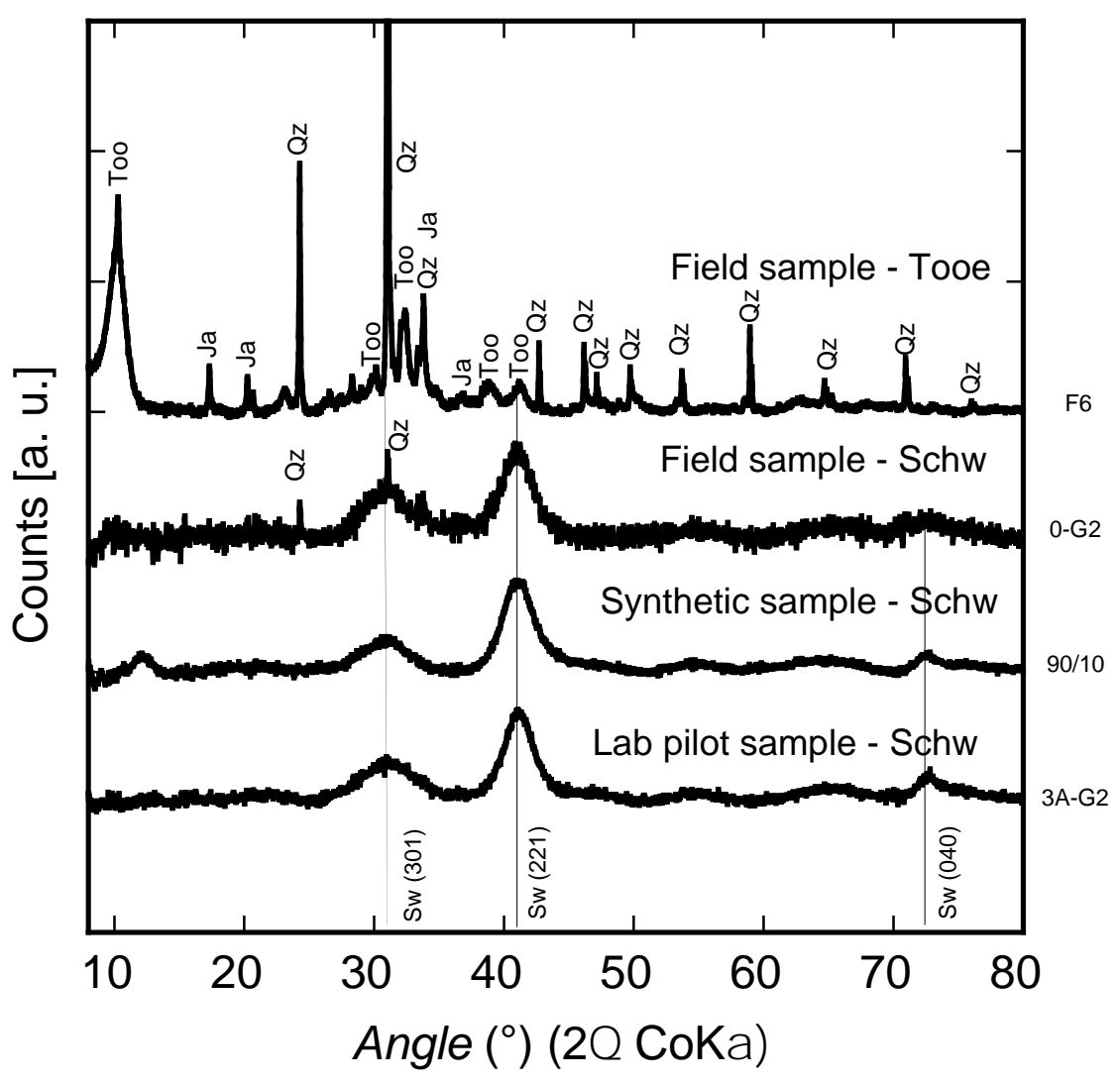

Figure S4: X-Ray powder diffraction data obtained for selected AMD samples used in this study (F6, $0-\mathrm{G} 2,90 / 10,3 \mathrm{~A}-\mathrm{G} 2$ ). Each diffractogram is representative for a group of samples presented in the Table 1. Too stands for reflexions from Tooeleite, Ja for Jarosite, Qz for quartz, and $\mathrm{Sw}$ for schwertmannite. 


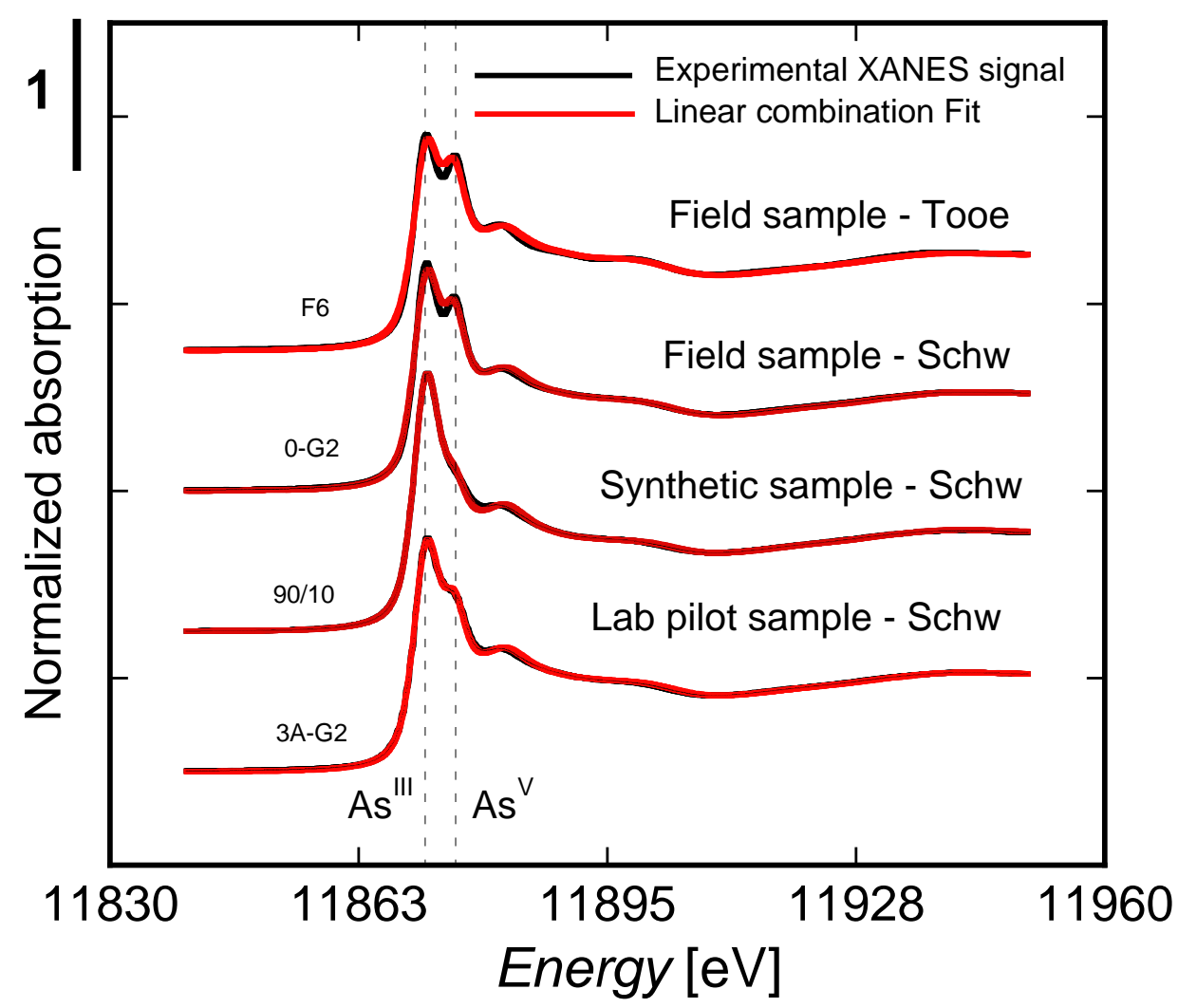

Figure S5: Examples of LCF reconstruction of experimental XANES spectra using the reference compounds presented in Figure S1. LCF decomposition is given for four samples representative of the groups presented in Table 1 and whose diffractogram is presented Figure S4. Such decomposition allows the determination of $\mathrm{As}(\mathrm{III}) / \Sigma$ As ratios for the AMD samples considered in this study. 